\title{
Effect of OKY 046, a thromboxane synthase inhibitor on lung vascular permeability after pulmonary embolism in sheep
}

\author{
SHLOMO LELCUK, JOSEPH M KLAUSNER, ARIE MERHAV, RON R ROZIN \\ From the Department of Surgery, Hadassah (Rokach) Hospital, Tel Aviv Medical Center, and the Sackler \\ School of Medicine, Tel Aviv University, Tel Aviv, Israel
}

ABSTRACT OKY 046, a specific thromboxane synthase inhibitor, was used to investigate wheth@̋ large pulmonary emboli, like microemboli, cause an increase in thromboxane $\mathrm{A}_{2}$ and an associated increase in vascular permeability in sheep. Nineteen sheep were anaesthetised and had cannulas inserted into the afferent lymphatic of the caudal mediastinal lymph node and pulmonary are carotid arteries. Several days later the animals were pretreated with placebo or OKY $0460.4 \mathrm{mg} / \mathrm{kg}$ one hour before being given clotted blood $0.5 \mathrm{~g} / \mathrm{kg}$ intravenously. After embolisation in the contro animals mean pulmonary artery pressure (MPAP) rose from 12 to $34 \mathrm{~mm} \mathrm{Hg}$ and pulmonary artery wedge pressure (PAWP) fell from 4.4 to $1.5 \mathrm{~mm} \mathrm{Hg}$; the cardiac index did not change but the physiological shunt (Q́s/QT) rose from $17 \%$ to $50 \%$. One hour after embolisation the platelet count fell from 76 to $32 \times 10^{6} / 1$ whereas at 15 minutes thromboxane $B_{2}$ rose from 116 to $560 \mathrm{pg} / \mathrm{ml}$ plasma and from 324 to $795 \mathrm{pg} / \mathrm{ml}$ in lymph $(\mathrm{p}<0.05)$. By 2 hours the concentration thromboxane $\mathrm{B}_{2}$ was higher in lymph than in plasma. Lymph flow rose from 8.7 to a maximum $\overline{\mathrm{Q} f}$ $27.3 \mathrm{ml} / \mathrm{h}$ at $15 \mathrm{minutes}$ but despite the increase in flow the lymph:plasma (L:P) protein ratio did not fall, indicating an increased permeability of the blood vessels to protein. Pretreatment with

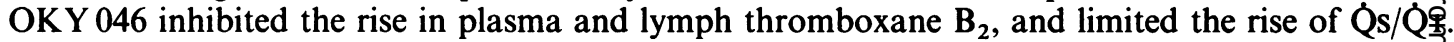
The changes in MPAP, PAWP, cardiac index, platelet count, lymph flow, and L:P protein ratio, however, were no different from those in untreated sheep. These results indicate that a large pulmonary embolus leads to an increase in plasma and lung lymph thromboxane $A_{2}$, whice moderates the rise in Q́s/Q́T in part but not the increase in vascular permeability.

Several reports have documented an increase in microvascular permeability in the lungs after the intravenous infusion of various microemboli, ${ }^{1}$ such as glass beads, air bubbles, barium sulphate, and platelets. ${ }^{2-4}$ The mechanism of the increase in permeability has been related to the activity of white blood cells ${ }^{5}$ and to thromboxane $\mathbf{A}_{2}{ }^{6}$ : leucopenia prevented the increase in permeability after air embolism, ${ }^{5}$ and inhibition of thromboxane synthase prevented the increase in permeability after thrombin infusion. ${ }^{6} \mathrm{~A}$ large pulmonary embolus causes platelet entrapment in the lungs and a rise in plasma

Address for reprint requests: Dr S Lelcuk, Department of Surgery, Hadassah (Rokach) Hospital, 8 Balfour Street, PO Box 51, Tel Aviv, Israel.

Accepted 4 February 1987 thromboxane $\mathbf{B}_{2}$, events similar to those accompanying microembolism produced by thrombin infusion.

This study tests the effect of a specific thromboxane synthesis inhibitor, OKY 046, on microvasculat permeability and haemodynamic changes after the injection of large blood clots intravenously int sheep.

\section{Methods}

Experiments were conducted in 19 sheep weighit $39-45 \mathrm{~kg}$. Animals were anaesthetised to allo cannulas to be inserted several days before pulmonary embolisation to avoid the effects of surgical trauma and anaesthesia at the time of embolisation. A cannula was inserted into the lymphatic channel draining into the cauda 
mediastinal lymph node by the technique described by Staub, ${ }^{7}$ a 14 gauge catheter was inserted into the jugular vein, a 7 French thermistor tipped catheter into the pulmonary artery (Instrumentation Laboratory, Lexington, Montana, USA), and a 20 gauge catheter into the carotid artery. On the day of the study $40 \mathrm{ml}$ blood was withdrawn and 10 units thrombin $/ \mathrm{ml}$ blood added. The clot was allowed to retract and after two hours the serum was decanted. The clot was cut into 3-5 $\mathrm{mm}$ cubes before intravenous infusion.

Measurements were conducted in awake sheep. Lymph was collected directly into a syringe from the cannula on the chest wall. A two hour collection was used to give a baseline lymph flow and protein ratio before embolisation. Measurements were taken at intervals up to four hours after embolisation. Strain gauge transducers (Bentley Laboratories, Irvine, California) were used to monitor the following pressures: mean pulmonary artery pressure, mean pulmonary artery wedge pressure, and mean arterial pressure. Cardiac output was measured in triplicate by thermodilution and divided by body weight to obtain the cardiac index. Blood gases, $\mathrm{pH}$, haemoglobin, and oxygen saturation (Instrumentation Laboratory, models 282 and 812 ) were measured in pulmonary arterial and systemic arterial blood to calculate oxygen content in mixed venous, arterial, and pulmonary capillary blood. The Berggren equation was then used to calculate the percentage physiological shunt $(\mathbf{Q} / \mathbf{Q}$ T), where $Q \mathbf{s}$ is blood flow leaving the lung with the same oxygen content as pulmonary arterial blood and QT is total flow. ${ }^{8}$ Blood and lymph samples were obtained before and 15, 30, 60, 120, and 240 minutes after embolisation.

Blood was collected in plastic syringes containing ethylene diamine tetra-acetic acid anticoagulant and aspirin, the later in a final concentration of $50 \mu \mathrm{g} / \mathrm{ml}$. Plasma was immediately separated by centrifugation at $4^{\circ} \mathrm{C}$, and then frozen at $-20^{\circ} \mathrm{C}$ for subsequent assay of thromboxane $B_{2}$ and 6-keto-prostaglandin $\mathrm{F}_{1 \alpha}\left(\mathrm{PGF}_{1 \alpha}\right)$. Aliquots of lymph were frozen for later prostanoid assay. All samples of plasma and lymph were coded and analysed blind. Radioimmunoassay for thromboxane $\mathrm{B}_{2}$ and 6-keto-PGF ${ }_{1 \alpha}$, the stable hydrolysis products of thromboxane $\mathrm{A}_{2}$ and prostacyclin respectively, were conducted with an antibody supplied by $\mathrm{Dr} L$ Levine, Brandeis University, as reported elsewhere. ${ }^{9}$ 'The protein content of plasma and lymph was measured and the lymph: plasma protein ratio calculated. ${ }^{10}$ Circulating platelet and white blood cell counts were measured by phase microscopy.

After baseline measurements animals were divided randomly and nine received saline placebo and 10 the imidazole derivative OKY 046 (kindly supplied by Ono Pharmaceutica, Osaka, Japan). This specific thromboxane synthase inhibitor was given in a dose of $0.4 \mathrm{mg} / \mathrm{kg}$. One hour later a clot was introduced into the jugular venous catheter. At the end of the experiment all animals were anesthetised and killed.

Statistical analysis to compare treated and control animals used analysis of variance and paired and non-paired $t$ tests. Significance was accepted if $\mathrm{p}<0.05$. Results are reported as means with standard errors.

\section{Results}

In the saline pretreated sheep embolisation caused a rise in mean pulmonary artery pressure from 12 to 34 $\mathrm{mm} \mathrm{Hg}$ at 15 minutes $(\mathrm{p}<0.05)$, and a return to 26 $\mathrm{mm} \mathrm{Hg}$ at 1 hour (fig 1). At 30 minutes mean central venous pressure had risen from 5.8 to $17.5 \mathrm{~mm} \mathrm{Hg}$ $(p<0.05)$ and mean pulmonary artery wedge

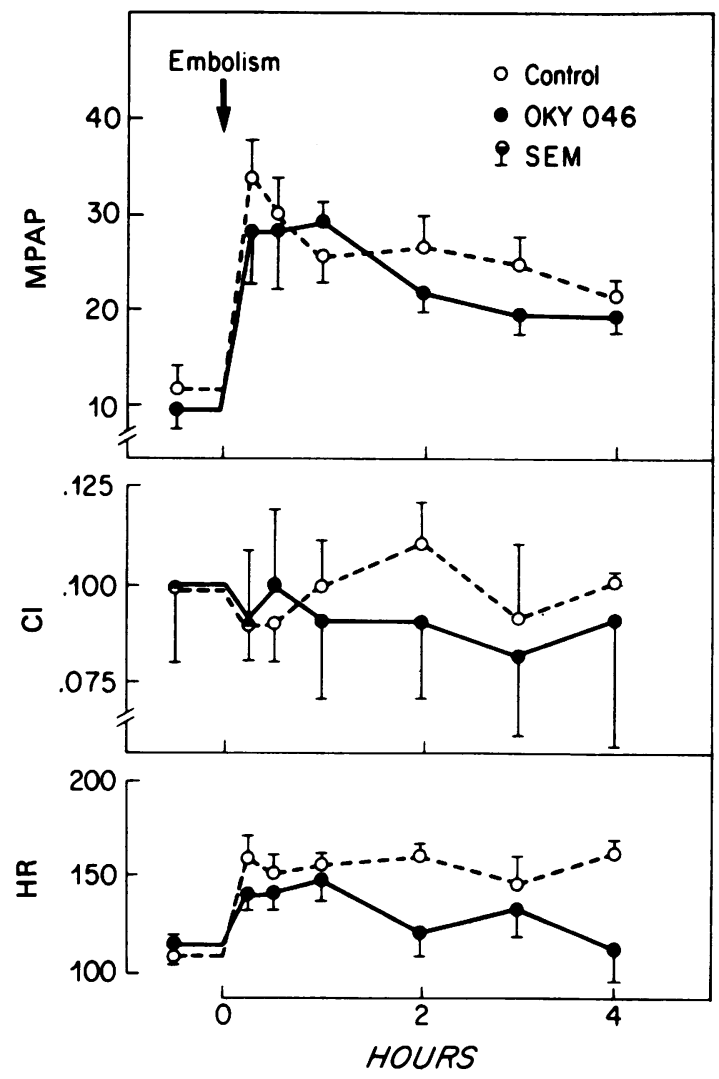

Fig 1 Changes in mean pulmonary artery pressure (MPAP, $\mathrm{mm} \mathrm{Hg})$, cardiac index $\left.(\mathrm{CI}), \mathrm{l} \mathrm{min}^{-1} \mathrm{~kg}\right)$, and heart rate ( $H R$, beats/min) after embolisation in sheep pretreated with OKY 046 or placebo. 


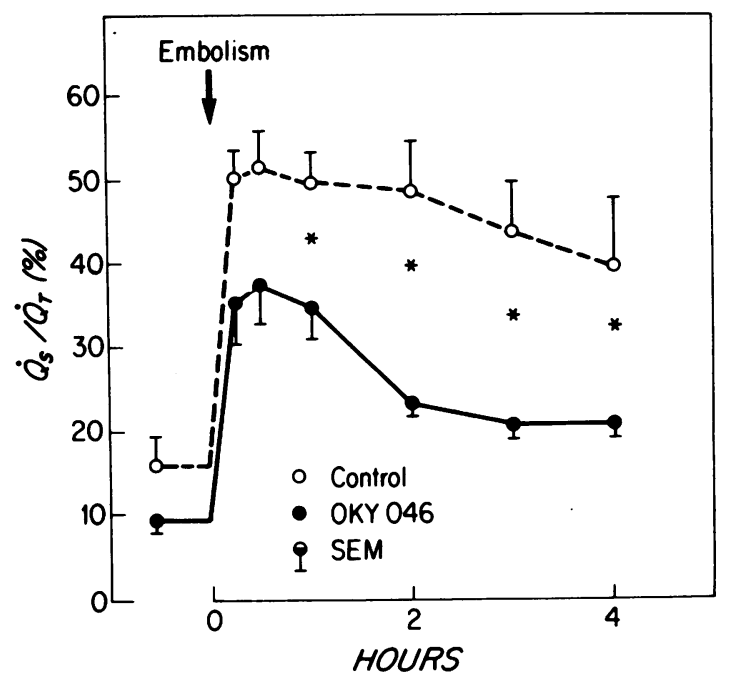

Fig 2 Change in physiological shunt $\left(\dot{Q}_{S} / \dot{Q}_{T}\right)$ after embolisation in sheep pretreated with OKY 046 or placebo. ${ }^{*} p<0.05$ for difference between groups.

pressure had fallen from 4.4 to $1.5 \mathrm{~mm} \mathrm{Hg}(\mathrm{p}<0.05)$. The cardiac index did not vary from a baseline value of $0.11 \mathrm{~min}^{-1} \mathrm{~kg}^{-1}$. Heart rate rose from 112 to 161 beats per minute at 15 minutes $(p<0.05)$ and mean arterial pressure rose insignificantly from a baseline value of 94 to $103 \mathrm{~mm} \mathrm{Hg}$. Qs/QT had risen at 15 minutes from $17 \%$ to $50 \%(\mathrm{p}<0.001$; fig 2 and table).

The mean platelet count fell from 75.5 to $31.8 \times 10^{6} / 1 \quad 15$ minutes after embolisation $(p<0.05)$. There was a non-significant increase in white blood cell count from a baseline value of $6 \times 10^{6} / 1$ to $8 \times 10^{6} / 1$ (table 1 ). Within 15 minutes of clot infusion there was an increase in plasma thromboxane $B_{2}$ from 116 to $560 \mathrm{pg} / \mathrm{ml}(\mathrm{p}<0.01)$ (fig 3) and in lymph thromboxane $B_{2}$ from 324 to 795 $\mathrm{pg} / \mathrm{ml}(\mathrm{p}<0.05)$. Two hours after embolisation plasma thromboxane $B_{2}$ levels continued to rise (table 2). At 1 hour there was an increase in plasma 6-keto-PGF ${ }_{1 \alpha}$ concentration from 40 to $308 \mathrm{pg} / \mathrm{ml}$ $(\mathrm{p}<0.05)$ and in lymph 6-keto-PGF ${ }_{1 \alpha}$ concentration from 210 to a peak of $1902 \mathrm{pg} / \mathrm{ml}$ (table 2).

After embolisation lymph flow rose from 8.7 to $27.3 \mathrm{ml} / \mathrm{h}$ at 15 minutes $(\mathrm{p}<0.001)$, returning to 17.7 $\mathrm{ml} / \mathrm{h}$ at 2 hours. The lymph-plasma protein ratio rose from a baseline value of 0.60 to 0.72 at 2 hours, though the change was not significant (fig 4). The fact that the lymph-plasma protein ratio did not fall indicates increased permeability of the lung vascular bed to protein and fluid. Pretreatment with OKY 046 prevented the rise of plasma and lymph thromboxane $\mathrm{B}_{2}$ concentrations (fig 3 ) and moderated the rise in QS/QT (fig 2). There were no differences in MPAP, PAWP, cardiac index, platelet counts, lymph flow, or lymph: plasma protein ratio between treated and control animals (figs 1 and 4).

\section{Discussion}

As anticipated, pulmonary embolism led to a rapid rise in MPAP and Qs/ST and a fall in platelet count. There was an increase in plasma and lymph thromboxane $B_{2}$ concentrations - though, surprisingly, lymph but not plasma thromboxane $\mathrm{B}_{2}$ levels remained raised. The change in lymph thromboxane $B_{2}$ levels occurred over the same time as the rise in

Table 1 Baseline data obtained before embolisation

\begin{tabular}{|c|c|c|c|c|c|c|c|c|c|c|c|c|c|c|c|c|c|c|c|c|c|c|c|}
\hline \multirow[b]{2}{*}{ Min } & & \multicolumn{2}{|c|}{$\begin{array}{l}\text { Heart } \\
\text { rate } \\
(/ \mathrm{min})\end{array}$} & \multicolumn{2}{|c|}{$\begin{array}{l}M A P \\
(\mathrm{~mm} H g)\end{array}$} & \multicolumn{2}{|c|}{$\begin{array}{l}M P A P \\
(m m H g)\end{array}$} & \multicolumn{2}{|c|}{$\begin{array}{l}M P W P \\
(\mathrm{~mm} H g) \\
\end{array}$} & \multicolumn{2}{|c|}{$\begin{array}{l}\text { CVP } \\
(\mathrm{mm} \mathrm{Hg}) \\
\end{array}$} & \multicolumn{2}{|c|}{$\begin{array}{l}\text { Cardiac } \\
\text { index } \\
\left(\operatorname{lmin}^{-1} \mathrm{~kg}\right)\end{array}$} & \multicolumn{2}{|c|}{$\underset{(\%)}{\dot{Q}_{S} / \dot{Q}_{T}}$} & \multicolumn{2}{|c|}{$\begin{array}{l}\text { Platelets } \\
\left(\times 10^{6} / l\right) \\
\end{array}$} & \multicolumn{2}{|c|}{$\begin{array}{l}W B C \\
\left(\times 10^{6} / l\right) \\
\end{array}$} & \multicolumn{2}{|c|}{$\begin{array}{l}\dot{Q} L \\
(m l / h) \\
\end{array}$} & \multicolumn{2}{|c|}{\begin{tabular}{ll} 
L:P & \multicolumn{1}{l}{. } \\
protein & $\bigcirc$ \\
ratio & 3 \\
\end{tabular}} \\
\hline & & $C$ & $T$ & $C$ & $T$ & $C$ & $T$ & $C$ & $T$ & $C$ & $T$ & $C$ & $T$ & $C$ & $T$ & $C$ & $T$ & $C$ & $T$ & $C$ & $T$ & $C$ & \\
\hline $\begin{array}{l}\text { Mean } \\
\text { SEM }\end{array}$ & 0 & $\begin{array}{l}112 \\
7 \cdot 0\end{array}$ & $\begin{array}{l}117 \\
6 \cdot 0\end{array}$ & $\begin{array}{l}94 \\
5 \cdot 0\end{array}$ & $\begin{array}{l}79 \\
2 \cdot 0\end{array}$ & $\begin{array}{l}12 \\
3 \cdot 0\end{array}$ & $\begin{array}{l}10 \\
1 \cdot 0\end{array}$ & $\begin{array}{l}4 \cdot 4 \\
1 \cdot 4\end{array}$ & $\begin{array}{l}3 \cdot 0 \\
0 \cdot 0\end{array}$ & $\begin{array}{l}5 \cdot 8 \\
0 \cdot 6\end{array}$ & $\begin{array}{l}3.7 \\
1.0\end{array}$ & $\begin{array}{l}0.1 \\
0.02\end{array}$ & $\begin{array}{l}0.1 \\
0.01\end{array}$ & $\begin{array}{l}17 \\
3 \cdot 0\end{array}$ & $\begin{array}{l}8 \cdot 7 \\
0 \cdot 5\end{array}$ & $\begin{array}{r}75 \cdot 5 \\
8 \cdot 5\end{array}$ & $\begin{array}{l}87 \\
10\end{array}$ & $\begin{array}{l}6.0 \\
0.98\end{array}$ & $\begin{array}{l}7.2 \\
0.92\end{array}$ & $\begin{array}{l}8 \cdot 7 \\
0 \cdot 6\end{array}$ & $\begin{array}{l}7 \cdot 6 \\
1 \cdot 1\end{array}$ & $\begin{array}{l}0.6 \\
0.08\end{array}$ & $\begin{array}{l}0.6 \text { 要 } \\
0.0 .8\end{array}$ \\
\hline $\begin{array}{l}\text { Mean } \\
\text { SEM }\end{array}$ & 15 & $\begin{array}{l}161 \\
12\end{array}$ & $\begin{array}{l}141 \\
9 \cdot 0\end{array}$ & $\begin{array}{l}103 \\
8 \cdot 0\end{array}$ & $\begin{array}{l}92 \\
6 \cdot 0\end{array}$ & $\begin{array}{l}34 \\
4 \cdot 0\end{array}$ & $\begin{array}{l}28 \\
4 \cdot 0\end{array}$ & $\begin{array}{l}5 \cdot 5 \\
8 \cdot 4\end{array}$ & $\begin{array}{l}5 \cdot 1 \\
1 \cdot 0\end{array}$ & $\begin{array}{l}14 \\
4 \cdot 0\end{array}$ & $\begin{array}{l}9 \cdot 1 \\
3 \cdot 0\end{array}$ & $\begin{array}{l}0.09 \\
0.02\end{array}$ & $\begin{array}{l}0.09 \\
0.01\end{array}$ & $\begin{array}{l}50 \\
3 \cdot 0\end{array}$ & $\begin{array}{l}36 \\
6 \cdot 0\end{array}$ & $\begin{array}{l}47 \cdot 4 \\
15\end{array}$ & $\begin{array}{l}72 \\
11\end{array}$ & $\begin{array}{l}5 \cdot 8 \\
0 \cdot 52\end{array}$ & $\begin{array}{l}6 \cdot 6 \\
0.84\end{array}$ & $\begin{array}{l}27 \\
4 \cdot 0\end{array}$ & $\begin{array}{r}18 \cdot 1 \\
4 \cdot 3\end{array}$ & $\begin{array}{l}0.65 \\
0.02\end{array}$ & \\
\hline $\begin{array}{l}\text { Mean } \\
\text { SEM }\end{array}$ & 30 & $\begin{array}{l}154 \\
9 \cdot 0\end{array}$ & $\begin{array}{l}143 \\
8 \cdot 0\end{array}$ & $\begin{array}{l}100 \\
9 \cdot 0\end{array}$ & $\begin{array}{l}89 \\
6 \cdot 0\end{array}$ & $\begin{array}{l}30 \\
4 \cdot 0\end{array}$ & $\begin{array}{l}28 \\
5 \cdot 0\end{array}$ & $\begin{array}{l}1.5 \\
0.9\end{array}$ & $\begin{array}{l}2.3 \\
0.9\end{array}$ & $\begin{array}{r}17 \cdot 5 \\
4 \cdot 0\end{array}$ & $\begin{array}{l}14 \\
3.0\end{array}$ & $\begin{array}{l}0.09 \\
0.02\end{array}$ & $\begin{array}{l}0.1 \\
0.01\end{array}$ & $\begin{array}{l}52 \\
4 \cdot 0\end{array}$ & $\begin{array}{l}38 \\
5 \cdot 0\end{array}$ & $\begin{array}{l}38 \\
9.0\end{array}$ & $\begin{array}{l}64 \\
11\end{array}$ & $\begin{array}{l}5 \cdot 5 \\
0.90\end{array}$ & $\begin{array}{l}5.6 \\
0.74\end{array}$ & $\begin{array}{l}16 \\
2 \cdot 0\end{array}$ & $\begin{array}{r}23.9 \\
3.4\end{array}$ & $\begin{array}{l}0.63 \\
0.02\end{array}$ & $\begin{array}{l}0 . \\
0 .\end{array}$ \\
\hline $\begin{array}{l}\text { Mean } \\
\text { SEM }\end{array}$ & 60 & $\begin{array}{l}157 \\
5.0\end{array}$ & $\begin{array}{l}148 \\
11\end{array}$ & $\begin{array}{l}98 \\
6 \cdot 0\end{array}$ & $\begin{array}{l}87 \\
6.0\end{array}$ & $\begin{array}{l}26 \\
3 \cdot 0\end{array}$ & $\begin{array}{l}29 \\
6 \cdot 0\end{array}$ & $\begin{array}{l}2 \cdot 3 \\
0 \cdot 3\end{array}$ & $\begin{array}{l}2 \cdot 3 \\
0 \cdot 3\end{array}$ & $\begin{array}{r}14 \cdot 7 \\
3 \cdot 0\end{array}$ & $\begin{array}{r}12.6 \\
3.0\end{array}$ & $\begin{array}{l}0.1 \\
0.01\end{array}$ & $\begin{array}{l}0.09 \\
0.01\end{array}$ & $\begin{array}{l}50 \\
3.0\end{array}$ & $\begin{array}{l}35 \\
4 \cdot 0\end{array}$ & $\begin{array}{r}31 \cdot 8 \\
4 \cdot 0\end{array}$ & $\begin{array}{l}56 \\
11\end{array}$ & $\begin{array}{l}6 \cdot 3 \\
0.75\end{array}$ & $\begin{array}{l}5.5 \\
0.83\end{array}$ & $\underset{20}{20}$ & $\begin{array}{r}24 \cdot 1 \\
5.4\end{array}$ & $\begin{array}{l}0.63 \\
0.03\end{array}$ & $\begin{array}{l}0.69 \\
0.05\end{array}$ \\
\hline $\begin{array}{l}\text { Mean } \\
\text { SEM }\end{array}$ & 120 & $\begin{array}{l}161 \\
6.0\end{array}$ & $\begin{array}{l}120 \\
11\end{array}$ & $\begin{array}{l}94 \\
7 \cdot 0\end{array}$ & $\begin{array}{l}86 \\
6 \cdot 0\end{array}$ & $\begin{array}{l}27 \\
3 \cdot 0\end{array}$ & $\begin{array}{l}22 \\
2 \cdot 0\end{array}$ & $\begin{array}{l}1 \cdot 7 \\
1 \cdot 2\end{array}$ & $\begin{array}{l}2 \cdot 0 \\
1 \cdot 0\end{array}$ & $\begin{array}{l}13 \\
3 \cdot 5\end{array}$ & $\begin{array}{r}10 \cdot 2 \\
3 \cdot 0\end{array}$ & $\begin{array}{l}0 \cdot 1 \\
0 \cdot 01\end{array}$ & $\begin{array}{l}0.09 \\
0.01\end{array}$ & $\begin{array}{l}49 \\
5 \cdot 0\end{array}$ & $\begin{array}{l}27 \\
3 \cdot 0\end{array}$ & $\begin{array}{l}54 \\
7.0\end{array}$ & $\begin{array}{l}68 \\
12\end{array}$ & $\begin{array}{l}7 \cdot 8 \\
1.9\end{array}$ & $\begin{array}{l}5 \cdot 1 \\
0.87\end{array}$ & $\begin{array}{r}17 \cdot 7 \\
2 \cdot 5\end{array}$ & $\begin{array}{r}15.8 \\
3.0\end{array}$ & $\begin{array}{l}0.72 \\
0.09\end{array}$ & $\begin{array}{l}0.5 \\
0.93\end{array}$ \\
\hline $\begin{array}{l}\text { Mean } \\
\text { SEM }\end{array}$ & 240 & $\begin{array}{l}160 \\
4 \cdot 0\end{array}$ & $\begin{array}{l}118 \\
14\end{array}$ & $\begin{array}{l}85 \\
6.0\end{array}$ & $\begin{array}{l}83 \\
3 \cdot 0\end{array}$ & $\begin{array}{l}22 \\
2 \cdot 0\end{array}$ & $\begin{array}{l}20 \\
2 \cdot 0\end{array}$ & $\begin{array}{l}1.0 \\
0.6\end{array}$ & $\begin{array}{l}1.7 \\
0.6\end{array}$ & $\begin{array}{l}7 \cdot 7 \\
2 \cdot 0\end{array}$ & $\begin{array}{l}3.7 \\
1.6\end{array}$ & $\begin{array}{l}0.1 \\
0.0\end{array}$ & $\begin{array}{l}0.09 \\
0.02\end{array}$ & $\begin{array}{l}41 \\
8 \cdot 0\end{array}$ & $\begin{array}{l}23 \\
3 \cdot 0\end{array}$ & $\begin{array}{l}53 \\
14\end{array}$ & $\begin{array}{l}68 \\
10\end{array}$ & $\begin{array}{l}8.4 \\
1.5\end{array}$ & $\begin{array}{l}5 \cdot 9 \\
1 \cdot 3\end{array}$ & $\begin{array}{r}14.6 \\
2.6\end{array}$ & $\begin{array}{r}14.2 \\
3.4\end{array}$ & $\begin{array}{l}0.66 \\
0.04\end{array}$ & $\begin{array}{l}0.6 \\
0.65\end{array}$ \\
\hline
\end{tabular}

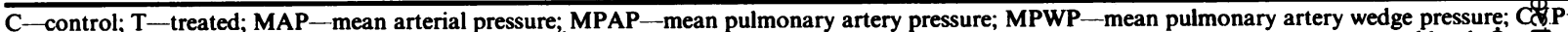

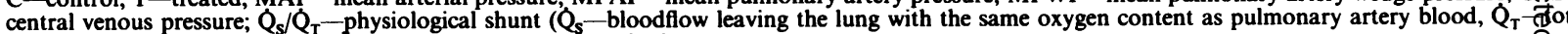
flow); WBC-white blood cells; $\mathrm{Q}$-lymph flow; L:P-lymph:plasma. 
Effect of thromboxane synthase inhibitor on lung vascular permeability after pulmonary embolism in sheep 679

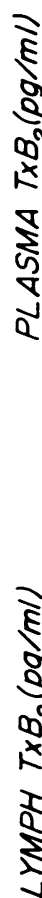

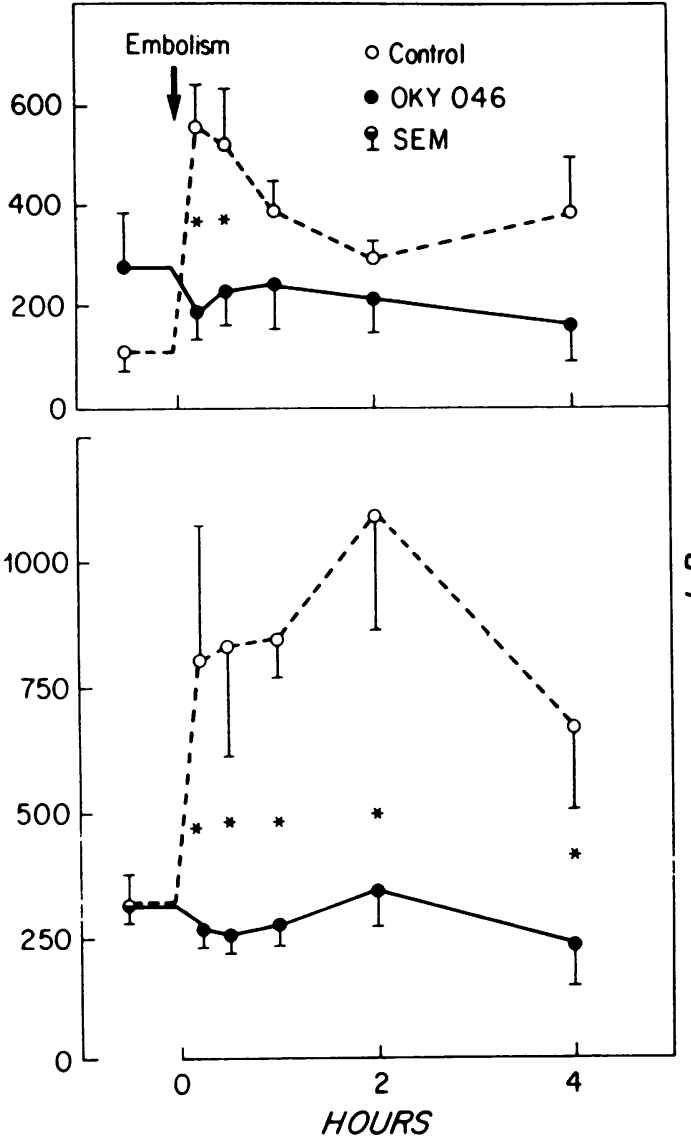

Fig 3 Plasma and lymph thromboxane $B_{2}$ concentrations after embolisation in sheep pretreated with $O K Y 046$ or placebo. ${ }^{*} p<0.05$.

physiological shunt (figs 2 and 3). The observation that OKY 046 prevented the increase in lymph and plasma thromboxane $\mathbf{B}_{2}$ completely, but only partially limited the rise in physiological shunt, indicates that other agents besides thromboxane $A_{2}$ are responsible for the reduced ventilation-perfusion

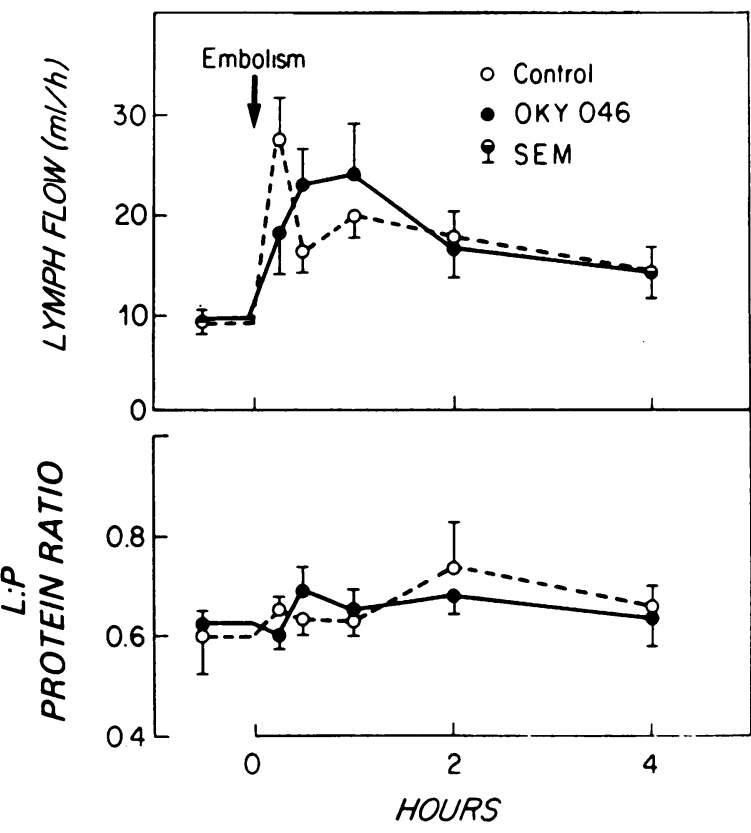

Fig 4 Lymph flow and the lymph:plasma protein ratio before and after embolisation in sheep pretreated with $O K Y$ 046 or placebo.

ratio and hypoxaemia. Other studies have documented the importance of serotonin (5-hydroxytryptamine). ${ }^{11}$

The observation that pulmonary embolism led to a twofold to threefold increase in lymph flow without a fall in the lymph-piasma protein ratio indicates an increase in the permeability of the vascular bed to fluids and proteins. An increase in hydrostatic pressures caused by partial vascular obstruction will induce an increase in fluid flow to the interstitium, but without a parallel increase in protein, so as the $L ; P$ protein ratio will fall. ${ }^{12}$ The rise in thromboxane $\mathbf{B}_{2}$ levels was not causally related to the increase in permeability since lymph flow and the lymph-plasma protein ratio were not altered when the synthesis of thromboxane $\mathrm{A}_{2}$ was inhibited (fig 4). In other

Table 2 Mean (SD) plasma and lymph thromboxane $B_{2}$ and 6-keto prostaglandin $F_{1 \alpha}\left(P G F_{1 \alpha}\right)$ concentrations (pg/ml) before and up to four hours after embolisation

\begin{tabular}{|c|c|c|c|c|c|c|c|c|}
\hline \multirow{3}{*}{$\begin{array}{l}\text { Time after } \\
\text { embolisation (min) }\end{array}$} & \multicolumn{4}{|c|}{ Thromboxane $B_{2}$} & \multicolumn{4}{|c|}{6 keto-PGF $1 \alpha$} \\
\hline & \multicolumn{2}{|l|}{ Plasma } & \multicolumn{2}{|l|}{ Lymph } & \multicolumn{2}{|l|}{ Plasma } & \multicolumn{2}{|l|}{ Lymph } \\
\hline & Control & Treated & Control & Treated & Control & Treated & Control & Treated \\
\hline $\begin{array}{r}0 \\
15 \\
30 \\
60 \\
120 \\
240\end{array}$ & $\begin{array}{l}116(30) \\
560(84) \\
524(107) \\
387(59) \\
284(35) \\
382(143)\end{array}$ & $\begin{array}{l}289(107) \\
189(42) \\
236(63) \\
241(92) \\
212(71) \\
161(76)\end{array}$ & $\begin{array}{c}324(66) \\
795(266) \\
838(227) \\
832(66) \\
1103(234) \\
671(156)\end{array}$ & $\begin{array}{l}318(55) \\
258(33) \\
247(41) \\
264(38) \\
342(80) \\
226(62)\end{array}$ & $\begin{array}{c}40(70) \\
160(50) \\
200(90) \\
308(355) \\
300(250) \\
270(220)\end{array}$ & $\begin{array}{c}45(60) \\
180(90) \\
300(100) \\
350(150) \\
290(200) \\
290(150)\end{array}$ & $\begin{array}{c}210(89) \\
1010(74) \\
1014(212) \\
1902(463) \\
1900(525) \\
1200(565)\end{array}$ & $\begin{array}{r}437(55) \\
537(132) \\
668(139) \\
810(147) \\
1450(140) \\
1055(307)\end{array}$ \\
\hline
\end{tabular}


settings the inhibition of thromboxane synthase has limited microvascular permeability as in microembolism induced by thrombin infusion, ${ }^{6}$ white blood cell activation induced either by complement ${ }^{13}$ or by calcium ionophore, ${ }^{14}$ acid aspiration, ${ }^{15}$ and ischaemia. ${ }^{16}$ Pulmonary embolism must activate permeability pathways in addition to those related to thromboxane $\mathbf{A}_{2}$. For example, platelets contain a high molecular weight agent that can induce permeability, ${ }^{17}$ or the interaction of an embolus with the lung could stimulate pulmonary mast cell synthesis of 5-lipoxygenase derived leukotrienes $\mathrm{C}_{4}$, $D_{4}$, and $E_{4}$-potent permeability promoting agents. ${ }^{18}$ Finally, clot may stimulate alveolar macrophages to secrete platelet activating factor, another agent that provokes permeability. ${ }^{19}$

The ability of a pulmonary embolus to trigger pulmonary metabolic activity in which the arachidonic acid cascade plays a part is shown by the rise in lymph concentrations of thromboxane $B_{2}$ and 6-keto-PGF ${ }_{1 \alpha}$. Presumably the major source of lymph 6-keto-PGF - $_{1 \alpha}$ is from endothelial cells stimulated by the thrombin clot. ${ }^{20}$ The sustained rise in pulmonary lymph thromboxane $B_{2}$ concentrations while plasma thromboxane $B_{2}$ concentrations fall suggests a metabolic source in the lung parenchyma. Pulmonary synthesis of thromboxane $A_{2}$ is known to occur in other settings, such as anaphylactic reactions, ${ }^{21}$ where the stimuli gain access to the lungs via the vasculature as in embolisation. Several types of pulmonary parenchymal cells, including mast cells, ${ }^{18}$ fibroblasts, ${ }^{22}$ and endothelial cells, ${ }^{23}$ have the capacity to synthesise thromboxane $\mathbf{A}_{2}$. It remains possible, however, that the thromboxane source is related directly to platelets entrapped in the lungs, and that these cells secrete thromboxane $B_{2}$, which in turn diffuses into lung interstitium.

In summary, pulmonary embolism leads to an increase in microvascular permeability, which appears not to depend solely on thromboxane $\mathbf{A}_{2}$ synthesis and mediation. This is in contrast to thrombin induced microembolisation, where the increase in permeability can be prevented by thromboxane inhibition. ${ }^{1}$

\section{References}

1 Minnear LF, Johnson A, Malik BA. $\beta$ Adrenergic modulation of pulmonary transvascular fluid and protein exchange. J Appl Physiol 1986;60:266-74.

2 Malik AB, Van dr Zee H. Lung vascular permeability following progressive embolization. J Appl Physiol 1978;45:590-7.

3 Ohkuda K, Nakahara K, Weidner J, Binder A, Staub NC. Lung fluid exchange after uneven pulmonary obstruction in sheep. Circ Res 1978;43:152-61.

4 Vaage J, Nicholaysen G, Waalen BA. Aggregation of blood platelets and increased hydraulic conductivity of pulmonary exchange vessels. Acta Physiol Scand 1976;98:175-84.

5 Tahamont MV, Malik AB. Granulocytes mediate lung vascular injury after thrombin. $J$ Appl Phys就 1983;54:1489-95.

6 Garcia-Szabo RR, Peterson MB, Watkins WB Bizios R, Kong DL, Malik AB. Thromboxane gener矢 tion after thrombin. Circ Res 1983;43:214-22.

7 Staub NC, Bland R, Brigham KL, Demling R, Erdma J, Woolverton W. Preparation of chronic lung fistulfs in sheep. J Surg Res 1975;19:315-20.

8 Berggren SM. The oxygen deficit of arterial blood caused by non-ventilating parts of the lung. Acta Physiol Scand 1942;11(suppl):1-92.

9 Utsunomiya T, Krausz MM, Levine L, Shepro Hechtman HB. Thromboxane mediation of cardixpulmonary effects of embolism. $J$ Clin Invesy 1980;70:361-8.

10 Gindler EM, Westgard JO. Automated and manufien determination of albumin with bromcresol green a $_{2}$ new ionic surfactant. Clin Chem 1983;19:647.

11 Huval WV, Mathieson MA, Stamp LI, et al. Therapeutic benefits of 5-hydroxytryptamine inhibition followifg pulmonary embolism. Ann Surg 1984;197:220-5.

12 Lelcuk S, Alexander F, Valeri CR, Shepro D, Hechtm HB. Thromboxane $A_{2}$ moderates permeability after limb ischemia. Ann Surg 1985;202:642-6.

13 McDonald JWD, Ali M, Morgan E, Townsend ER Cooper JD. Thromboxane synthesis by sources othes than platelets in association with complement induced pulmonary leukotrienes and pulmonary hypertension in sheep. Circ Res 1983;82:1-6.

14 Dunham BM, Hechtman HB, Valeri CR, Shepro Anti-inflammatory agents inhibit microvascular pơ meability induced by leukotrienes and by stimulategd human neutrophils. Microcirculation, Endothelium and Lymphatics 1984;1:460-89.

15 Huval WV, Dunham B, Lelcuk S, Valeri CR, Shepro B, Hechtman HB. Thromboxane mediation of cardievascular dysfunction following aspiration. Surge्wy 1983;94:259-66.

16 Lelcuk S, Alexander F, Valeri CR, Shepro D, Hechtma HB. Ischemia stimulates tissue thromboxane syojthesis. Surgical Forum 1984;35:76-8.

17 Nachman RL, Weksler B, Ferris B. Characterization off human platelet vascular permeability-enhancing activ: ity. J Clin Invest 1972;51:549-56.

18 Lewis RA, Austen KF. Mediation of local homeostasis and inflammation by leukotrienes and other mast cetdependent compounds. Nature 1981;293:103-8.

19 Hanahan DJ, Demopoulos DJ, Liehr J, Dinkard RA. Identification of PAF isolated from rabbit basophis as acetyl glyceryl ether phosphorylcholine. $J$ Biol Chem 1980;225:5415-6.

20 Weksler BB, Ley CW, Jaffe EA. Stimulation of end thelial cell prostacyclin production by thrombir, trypsin and the ionophore A23187. J Clin Invest 1978;62:923-30.

21 Schulman SE, Newball HH, Demers L, Fitzpatrick AF, Adkinson FN jun. Anaphylactic release of throfiboxane $A_{2}$, prostaglandin $I_{2}$ and prostacyclin from human lung parenchyma. Am Rev Respir B̈is 1981;124:402-6.

22 Hopkins NK, Sun FF, Gorman RR. Thromboxane $\mathbb{R}_{2}$ biosynthesis in human lung fibroblasts WI-38. B⿺辶chem Biophys Res Comm 1978;85:827-36.

23 Dunham B, Shepro D, Hechtman HB. Leukotriense induction of $\mathrm{TxB}_{2}$ in cultured bovine aortic enfothelial cells. Inflammation 1984;8:313-21. 